\title{
PENGARUH MEDIA E-LEARNING DAN MOTIVASI BELAJAR TERHADAP IPK AKADEMIK MAHASISWA STKIP PANCA SAKTI
}

\author{
Nadia Rista \\ Universitas Panca Sakti, Bekasi, Indonesia \\ nadiarista59@gmail.com
}

Received: 04 Januari 2021

Revised: $\quad 06$ Februari 2021

Accepted: 13 Maret 2021

\begin{abstract}
The purpose of the research is to examine the level of positive and significant (1) influence e-learning media to GPA of students in economic educationt program study year 2019/2020 in STKIP Panca Sakti, (2) influence learning motivation to academic GPA of students in economic educationt program study year 2019/2020 in STKIP Panca Sakti. The population of the research is students at economic educationt program study year 2019/2020 that amounts 697 students. The sampling technique used is the propotional random sampling, wich then obtained a sample of 255 students. Method of collecting data by using documentation and questionnaire. Data analysis method used descriptive analysis and multiple regression analysis. The result showed that (1) e-learning media significantly influence to academic GPA of students in economic educationt program study year 2019/2020 in STKIP Panca Sakti, (2) learning motivation significantly influence to academic GPA of students in economic educationt program study year 2019/2020 in STKIP Panca Sakti.
\end{abstract}

Keywords: E-Leraning; Media; Learning Motivation; GPA

(*) Corresponding Author: Rista, nadiarista59@gmail.com, +62 82218769106

How to Cite: Rista, Nadia. (2021). Pengaruh Media E-Learning Dan Motivasi Belajar Terhadap IPK Akademik Mahasiswa STKIP Panca Sakti. Research and Development Journal of Education, 7 (1), 126135.

\section{INTRODUCTION}

Dunia teknologi informasi yang berkembang pesat pada saat ini mempengaruhi berbagai sisi kehidupan manusia. Perekembangan ini, mempunyai dampak yang sangat besar dalam berbagai sisi kehidupan, mulai dari keputusan pemerintah, pengadministrasian, perekonomian, bahkan pendidikan. Dari sudut pandang pemerintahan, sekarang ini mulai dikenal dengan istilah e-government, sedangkan dalam bidang perekonomian semua orang sudah mengenal dengan istilah pasar seperti $e$ commerce, e-business, e-marketing, bahkan program pemerintah yang ada saat ini yang sudah kita rasakan adalah $e$-KTP. Dibidang pendidikan mulai saat ini, teknologi informasi sudah banyak digunakan untuk kepentingan belajar, bahkan dalam pembelajaran dikenal dengan istilah terbarunya, yaitu e-learning (Suharyanto, \& Mailangkay, 2018). Perkembangan yang demikian didukung karena persediaan perangkat lunak maupun perangkat keras yang semakin hari terus meningkat untuk menunjang proses pembelajaran.

Pemanfataan teknologi informasi dari web based learning seperti e-learning (salah satunya) akan memberikan perubahan yang sangat berarti, baik dari hal sistem pendidikan yang mau dikembangkan, materi yang disampaikan, bagaimana proses instruksional dan pembelajaran akan dilakukan, serta hambatan-hambatan yang nantinya dihadapi baik oleh 
mahasiswa, dosen, dan penyelenggara pendidikan yang lainnya. Penggunaan media seperti e-learning pada saat proses pembelajaran diharapkan sebagai alternative untuk mengatasi masalah-masalah belajar yang dialami mahasiswa, karena penggunaan media e-learning membantu mengajarkan mahasiswa mencari dan mempelajarai ilmu pengetahuan yang lebih luas di dunia inet sehingga memunculkan kreativitas mahasiswa dalam mempelajari ilmu pengetahuan. Selain itu, dengan adanya pembelajaran e-learning juga diharapkan kognitif mahasiswa terhadap hasil IPK yang baik dapat mudah tercapai.

Berbagai pertimbangan melalui latar belakang dunia pendidikan yang semakin maju, Para pengembang media pembelajaran memilih untuk menciptakan media yang mampu menarik perhatian siswa secara mandiri. Menurut Uno (2016:40) studi yang dilakukan di Amerika sangat mendukung perkembangan e-learning, dengan menyatakan e-learning sangat efektif, berkemungkinan sebanyak $30 \%$ pendidikan menjadi lebih baik, sebanyak $40 \%$ waktu lebih singkat, dan sebanyak 30\% biaya lebih murah (Wardiana, 2002). Pembelajaran elektronik menurut Munir (2008:164), merupakan proses pembelajaran yang menggunakan bantuan perangkat elektronika. Penulis memilih menggunakan situs web sebagai pengembangan media pembelajaran (e-learning) dibandingkan dengan media yang lain, sebab web sebagai fasilitas belajar daring memiliki kelebihan dalam pemebelajaran di kelas sebagai berikut:

a. Memudahkan mahasiswa dalam mengakses media pembelajaran melalui perangkat gawai

b. Dapat menjadi pengganti media pembelajaran berbentuk buku cetak sehingga lebih mudah diakses kapanpun dan dimanapun

c. Tidak memiliki beban yang berat pada media pembelajaran, karena hanya butuh membawa gawai masing-masing mahasiswa saja.

d. Konten dapat diubah atau diperbaharui melalui rumus koding

e. Dapat ditambahkan fitur yang menarik untuk dilihat seperti desain ilustrasi dan foto

f. Membutuhkan interaksi mahasiswa, sehingga mahasiswa lebih tertantang dan mandiri dalam mengakses materi

Dalam setiap proses pembelajaran, ada beberapa unsur yang perlu diperhatikan dalam melaksanakan kegiatan belajar mengajar (Hakin, 2010; Hasyim, 2014), salah satunya adalah motivasi belajar. Menurut Uno (2014:23) Motivasi Belajar merupakan dorongan yang berasal dari diri seseorang baik internal maupun eksternal untuk melakukan perubahan perilaku melalui beberapa unsur atau indikator yang mendukung. Motivasi belajar mahasiswa dikatakan tinggi apabila mahasiswa memiliki sifat tekun dalam menghadapi tugas, ulet menghadapi setiap permasalahan yang ada, dan mempunyai minat terhadap kegiatan proses pembelajaran (Uno, 2014). Ciri-ciri motivasi belajar seperti ulet, tekun, mandiri, percaya diri, dan senang mengerjakan tugas yang diberikan (Sardiman, 2012:83), terbentuk pada diri mereka. Ada beberapa indikator motivasi belajar seperti kegiatan yang menarik dalam belajar, adanya penghargaan dalam belajar, dan lingkungan belajar yang kondusif (Uno, 2016:23), dan itu belum tampak dalam proses pembelajaran. Masih adanya permasalahan tersebut menunjukkan motivasi belajar mahasiswa masih rendah dalam diri mahasiswa program studi (prodi) pendidikan ekonomi. Masih ditemui permasalahan dalam proses pembelajaran yaitu motivasi belajar mahasiswa yang rendah yang ditandai dengan penyelesaian tugas dari dosen yang sering bahkan selalu ditunda-tunda, karena mahasiswa lebih senang dengan tugas-tugas yang sederhana.

Media pembelajaran e-learning diharapkan dapat memicu motivasi belajar mahasiswa (Aurora \& Effendi, 2019). Manurung (2017) mengatakan bahwa apabila motivasi belajar meningkat maka indeks prestasi kumulatif mahasiswa dapat meningkat. 
Sedangkan, motivasi belajar yang rendah dapat menurunkan indeks prestasi kumulatif mahasiswa. Ada beberapa faktor yang menyebebakan turunnya prestasi mahasiswa, diantaranya faktor internal dan faktor eksternal individu (Fakhrul, 2014; Alang, 2015).

Untuk melihat keterkaitan antara media pembelajaran e-learning, motivasi belajar, dan indeks prestasi kumulatif mahasiswa, dapat dilihat pada gambar berikut ini:

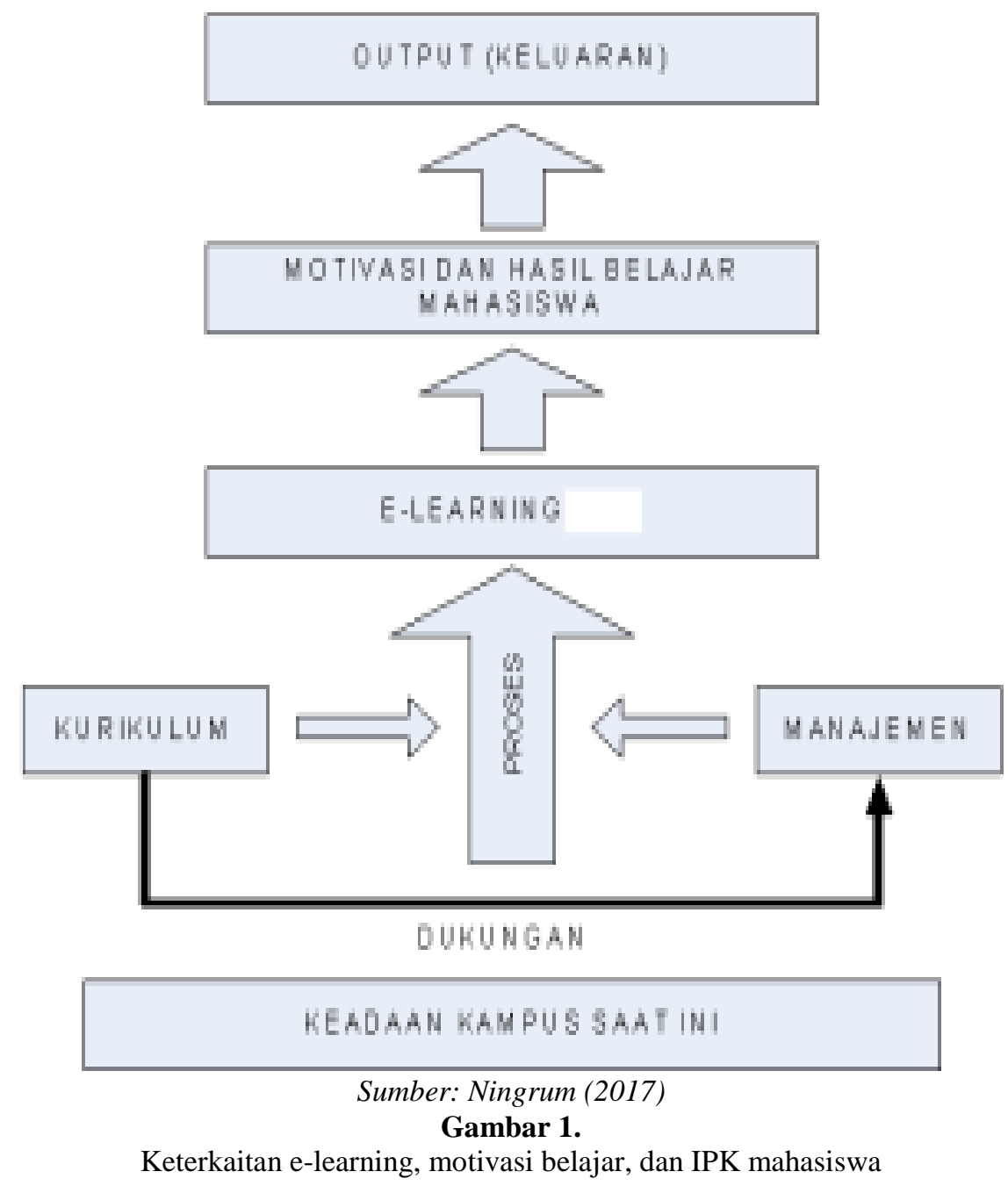

\section{LITERATURE REVIEW}

\section{Media E-Learning}

Media pembelajaran merupakan wahana penyalur pesan dan informasi belajar yang dirancang secara baik untuk membantu peserta didik dalam mencerna dan memahami materi pelajaran (Muhson, 2010). Ada beberapa jenis media pembelajaran, yaitu media pembelajaran visual, media pembelajaran Pemilihan suatu jenis media pembelajaran merupakan salah satu bagian terpenting dalam proses pembelajaran di kelas (Aghni, 2018). Salah satunya adalah media pembelajaran e-learning.

Ningrum (2017) mengartikan e-learning sebagai proses instruksi yang melibatkan penggunaan peralatan elektronik dalam menyampaikan, menilai, menciptakan, membantu perkembangan, dan memudahkan semua proses 
pembelajaran yang berpusat pada mahasiswa serta dilakukan secara interaktif dimanapun dan kapanpun pembelajaran jarak jauh yang diinginkan. Menurut Jethro, Grace, \& Thomas (2012) E-learning menyajikan lingkungan belajar yang sama sekali baru bagi siswa, sehingga membutuhkan keahlian yang berbeda untuk keberhasilan belajar, bahkan dapat meningkatkan keterampilan berpikir kritis, penelitian, dan evaluasi semakin penting karena mahasiswa memiliki volume belajar yang berbeda.

Media pembelajaran e-larning di STKIP/Universitas Panca Sakti bisa dilihat pada gambar berikut ini:

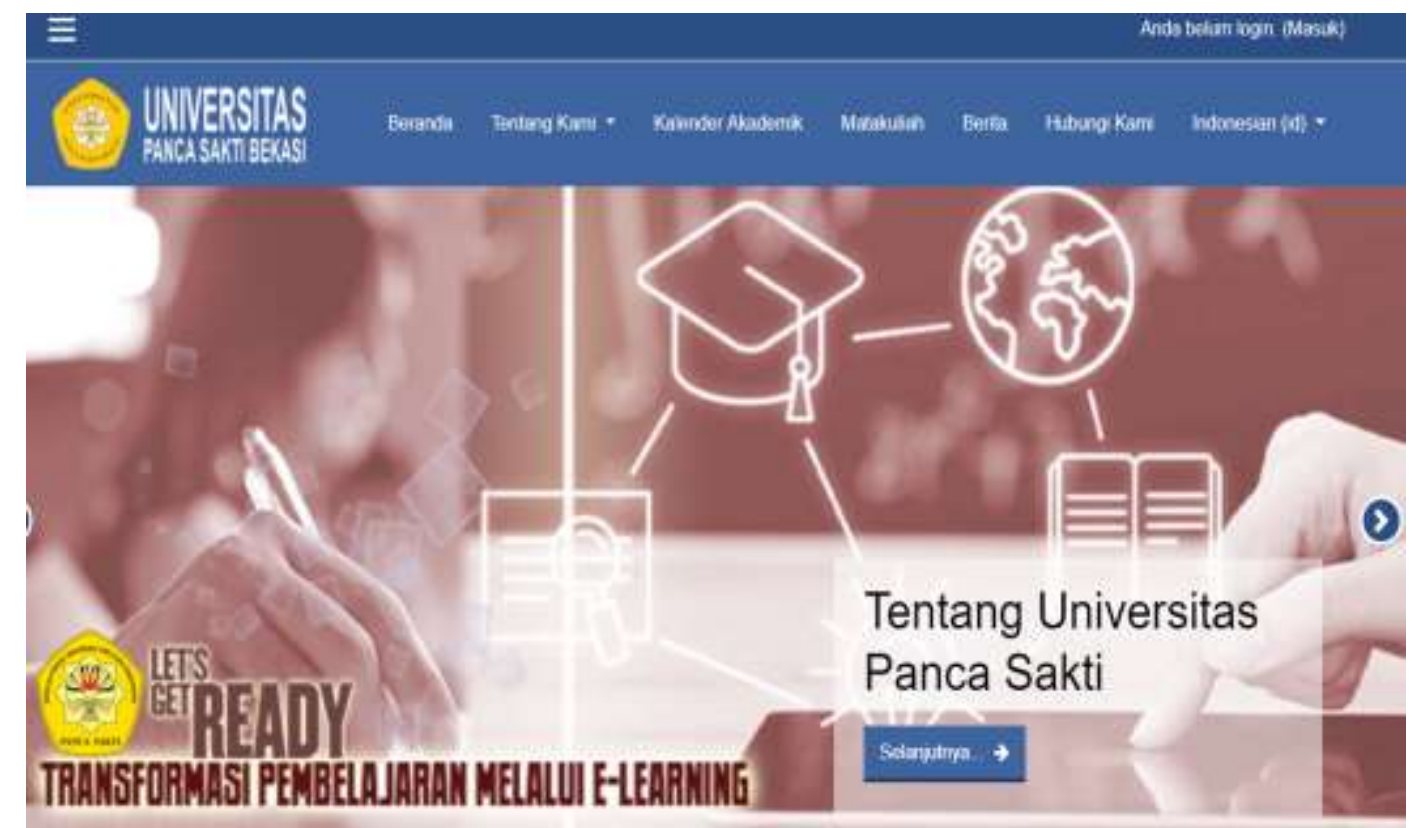

Sumber: Peneliti (2020)

Gambar 2.

Laman e-learning STKIP Panca Sakti
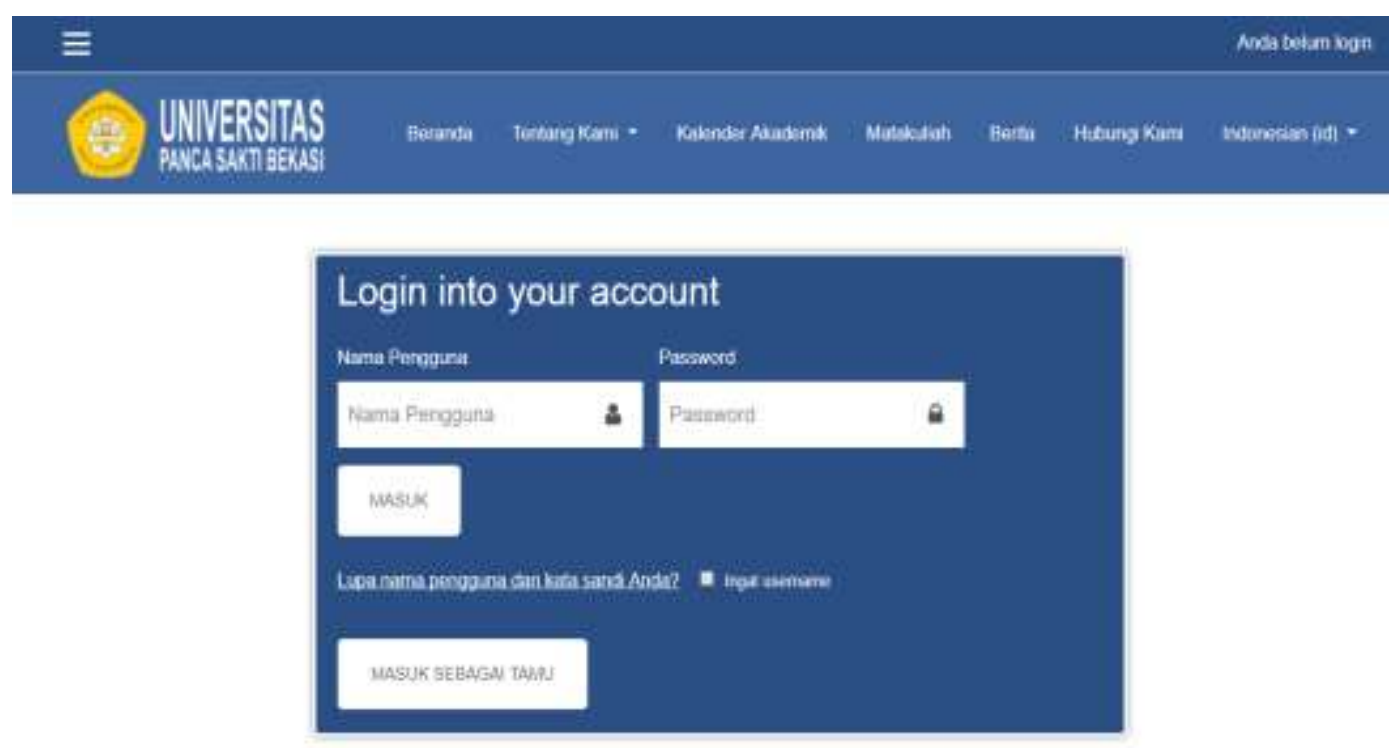

Sumber: Peneliti (2020)

Gambar 3.

Laman login e-learning STKIP Panca Sakti 
Ada beberapa kelebihan dan hambatan penggunaan media pembelajaran $e$ learning (Ningrum, 2017):

Kelebihan E-Learning :

1. Pengalaman pribadi dalam belajar

2. Mengurangi biaya

3. Kemampuan bertanggung jawab

4. Fleksibilitas

5. Personalisasi

6. Standarisasi

7. Efektivitas

8. Kecepatan

Hambatan E-Learning :

1. Investasi

2. Budaya

3. Teknologi dan Infrastruktur

4. Desain Materi

\section{Motivasi Belajar}

Menurut Hamdu \& Agustina (2011) motivasi merupakan suatu hal yang berdampak pada kesuksesan aktifitas pembelajaran mahasiswa. Tanpa adanya motivasi, proses pembelajaran akan sulit mencapai kesuksesan yang optimum. Nurmala, Tripalupi, \& Suharsono (2014) mendefenisikan motivasi belajar sebagai kecenderungan mahasiswa untuk melakukan kegiatan belajar yang dimotivasi oleh keinginan untuk mendapatkan hasil belajar yang sangat baik. Motivasi belajar yang mahasiswa miliki pada setiap kegiatan pembelajaran yang berperan untuk meningkatkan prestasi belajar mahasiswa dalam mata perkuliahan tertentu (Nashar, 2004:11). Mahasiswa dengan motivasi yang tinggi dalam belajar berkemungkinan untuk memperoleh hasil belajar yang tinggi, artinya tingginya motivasi mahasiswa akan semakin intensitas usahanya, semakin banyak upaya yang dilakukannya, maka semakin tinggi prestasi belajar yang diperolehnya (Hamdu \& Agustina, 2011). Menurut Makmun (dalam Ricardo, \& Meilani, 2017), ada delapan indikator penting untuk mengukur motivasi belajar, yaitu; durasi belajar, tingkat aspirasi yang hendak dicapai dengan kegiatan yang dilakukan, tingkat kualifikasi prestasi/produk (output) yang dicapai dari kegiatan yang dilakukan, frekuensi belajar, persistensi pada kegiatan belajar, ketabahan, keuletan dan kemampuan dalam menghadapi rintangan dan kesulitan, devosi dan pengorbanan untuk mencapai tujuan, dan arah sikap terhadap sasaran kegiatan.

\section{IPK}

Dalam proses pendidikan tinggi Indeks Prestasi Kumulatif (IPK) merupakan indikator keberhasilan mahasiswa (Tampil, Komaliq, \& Langi, 2017). Menurut Wicaksono (2012) Indeks Prestasi Kumulatif (IPK) merupakan angka kumulatif yang kemajuan belajar mahasiswa atau menunjukkan hasil belajar mahasiswa mulai dari semester pertama sampai dengan semester paling akhir yang telah ditempuh.

\section{METHODS}

Penelitian ini termasuk jenis penelitian kuantitatif kausatif (Badri, 2012). Populasi pada penelitian ini yaitu para mahasiswa Program Studi Pendidikan Ekonomi Tahun 
Akademik 2019/2020 yang berjumlah 697 orang mahasiswa. Pengambilan sampel pada penelitian ini menggunakan teknik proposional random sampling yang berjumlah 255 orang mahasiswa. Teknik analisis data yang digunakan dalam penelitian ini adalah analisis deskriptif melalui analisis regresi berganda serta uji hipotesis menggunakan uji $\mathrm{F}$, Koefisien Determinasi dan Uji t (Idris, 2010).

Dalam penelitian ini peneliti ingin mengetahui bagaimana (1). Pengaruh Media Pembelajaran Elektronik (E-Learning) terhadap IPK Mahasiswa Program Studi (prodi) Pendidikan Ekonomi TA 2019/2020 STKIP Panca Sakti, (2). Pengaruh Motivasi Belajar terhadap IPK Mahasiswa Program Studi Pendidikan Ekonomi TA 2019/2020 STKIP Panca Sakti, (3). Pengaruh Media Pembelajaran Elektronik (E-Learning) dan Motivasi Belajar terhadap IPK Mahasiswa Program Studi (prodi) Pendidikan Ekonomi TA 2019/2020.

\section{RESULTS \& DISCUSSION}

\section{Results}

Sebelum dilaksanakan uji analisis regresi linier berganda, ada beberapa langkah yang harus dilakukan sebagai uji prasyarat, yaitu uji normalitas data, dan uji multikolonioeritas data. Pengujian normalitas data bertujuan untuk mengetahui apakah data bersifat normal atau tidak normal. Hal ini berguna untuk landasan penggunaan uji statistic parametrik atau uji statistic non-parametrik. Pengujian normalitas data pada penelitian ini dapat dilihat pada table dibawah ini:

Tabel. 1

Uji Normalitas Data

\begin{tabular}{|c|c|c|c|c|}
\hline & & Learning & Motivasi & IPK \\
\hline \multicolumn{2}{|l|}{$\mathrm{N}$} & 55 & 55 & 55 \\
\hline \multirow[t]{2}{*}{ Normal Parameters ${ }^{\mathrm{a}}$} & Mean & 4.6549 & 3.5333 & .0511 \\
\hline & Std. Deviation & .71759 & 5.12201 & 40815 \\
\hline \multirow{3}{*}{$\begin{array}{ll}\text { Most } & \text { Extreme } \\
\text { Differences } & \end{array}$} & Absolute & 061 & 062 & 061 \\
\hline & Positive & 061 & 046 & 031 \\
\hline & Negative & .043 & .062 & .061 \\
\hline \multicolumn{2}{|l|}{ Kolmogorov-Smirnov Z } & 968 & 997 & 980 \\
\hline \multicolumn{2}{|c|}{ Asymp. Sig. (2-tailed) } & 305 & 274 & 292 \\
\hline
\end{tabular}

Sumber: SPSS (2020)

Berdasarkan tabel 1 di atas dapat dilihat hasil pengujian normalitas data pada penelitian ini bahwa nilai Asymp Sig. (2-tailed) setiap variable >0,050, maka dapat disimpulkan bahwa data penelitian bersifat normal atau berdistribusi secara normal. Pengujian multikolonieritas merupakan uji untuk mengetahui apakah data bersifat multikolonier (bercabang) atau tidak multikolonier (tidak bercabang). Data dapat dikatakan tidak terjadi multikolonearitas dalam model regresi apabila nilai tolerance > 0,10 dan data dapat dikatakan terjadi multikolonearitas dalam model regresi apabila nilai tolerance $<0,10$. Pengujian multikolonieritas dapat dilihat pada tabel2 dibawah ini: 
Tabel. 2

Uji Multikolonieritas Data

\begin{tabular}{lcc}
\hline \multirow{2}{*}{ Model } & \multicolumn{2}{c}{ Collinearity Statistics } \\
& Tolerance & VIF \\
\hline (Constant) & & \\
E-learning & .975 & 1.026 \\
Motivasi & .975 & 1.026 \\
\hline Sumber: SPSS (2020) & &
\end{tabular}

Berdasarkan hasil dari tabel di atas dapat dilihat nilai tolerance pada setiap variabel $<0,10$, maka dapat disimpulkan bahwa data penelitian ini bersifat multikolonieritas. Pengujian regresi linier berganda menggunakan uji $f$ dan uji t. hasil perhitungan uji $t$ dapat digunakan untuk melihat pengaruh setiap variable bebas terhadap variable terikat. Hasil pengujian regresi linier berganda dapat dilihat pada tabel dibawah:

Tabel. 3

Uji Regresi Linier Berganda

\begin{tabular}{lccccc}
\hline Model & $\begin{array}{c}\text { Unstandardized } \\
\text { Coefficients } \\
\text { Std. Error }\end{array}$ & $\begin{array}{c}\text { Standardized } \\
\text { Coefficients } \\
\text { Beta }\end{array}$ & $\mathbf{t}$ & Sig. \\
\hline (Constant) & .994 & 246 & & .120 & .000 \\
Elearning X1 & 010 & 003 & 231 & .754 & .000 \\
Motivasi X2 & 005 & 002 & 167 & .719 & .007 \\
\hline
\end{tabular}

Sumber : SPSS (2020)

Tabel. 4

Model Summary

\begin{tabular}{ccccc}
\hline Model & R & R Square & Adjusted R Square & Std. Error of the Estimate \\
\hline 1 & 263 & 069 & .062 & .39535 \\
\hline Sumber : SPSS (2020) & & &
\end{tabular}

Berdasarkan hasil uji regresi liner berganda pada tabel 4 dan tabel 5 di atas dapat dilihat bahwa dioeroleh nilai $\mathrm{Y}=1,994+0,010 \mathrm{X}_{1}+0,005 \mathrm{X}_{2}$. Dari hasil uji regresi liner berganda di atas dapat dilihat nilai koefisien determinasi sebesar 0,062 atau 6,2\%. Artinya, kontribusi penelitian dari variable E-Learning dan Motivasi Belajar Terhadap IPK Akademik Mahasiswa sebesar 6,2\%, sedangkan 93,8\% dipengaruhi oleh variable lain yang tidak diteliti dalam penelitian ini. Berdasarkan tabel 4 dan tabel 5 di atas juga dapat dilihat hasil sebagai berikut:

a) Media Pembelejaran E-Learning Pada IPK Akademik Mahasiswa

Dalam penelitian ini adalah untuk mengetahui signifikansi pengaruh media pembelajaran elektronik (elearning) (X1) terhadap IPK Akademik Mahasiswa Semester Ganjil 2019-2020 (Y). dari hasil analisis dapat dilihat bahwa nilai t hitung untuk variabel media pembelajaran elektronik (elearning) (X1) adalah $3.754>\mathrm{t}$ tabel 1.960 (sig. $0.000<0.05$ ) maka Ho ditolak. Dengan demikian dapat dikatakan bahwa media pembelajaran elektronik (elearning) mempunyai pengaruh signifikan terhadap IPK Akademik Mahasiswa Semester Genap 2019-2020 Program Studi Pendidikan Ekonomi di STKIP Panca Sakti. 
b) Motivasi Belajar Pada IPK Akademik Mahasiswa

Dalam penelitian ini adalah untuk mengetahui signifikansi pengaruh motivasi belajar (X2) terhadap IPK Akademik Mahasiswa Semester Ganjil 2019-2020 (Y). Dari hasil analisis dapat dilihat bahwa nilai t hitung untuk variabel motivasi belajar (X2) adalah $2.719>\mathrm{t}$ tabel 1.960 (sig. $0.007<0.05$ ) maka Ho ditolak. Dengan demikian dapat dikatakan bahwa motivasi belajar (X2) mempunyai pengaruh yang signifikan terhadap IPK Akademik Mahasiswa Semster Genap 2019-2020 Program Studi Pendidikan Ekonomi di STKIP Panca Sakti.

Untuk mengetahui apakah terdapat pengaruh media pembelajaran e-learning dan motivasi belajar terhadap IPK belajar akademik mahasiswa dilihat dari hasil uji F. dapat dilihat pada tabel dibawah:

Tabel. 5

Uji F

\begin{tabular}{lccccc}
\hline Model & $\begin{array}{c}\text { Sum of } \\
\text { Squares }\end{array}$ & f & Mean Square & F & Sig. \\
\hline regression & .924 & & 1.462 & .355 & 000 \\
residual & 9.388 & 52 & .156 & & \\
total & 2.312 & 54 & & & \\
\hline Sumber: $S P S S(2020)$ & & & &
\end{tabular}

Berdasarkan tabel di atas dapat dilihat bahwa nilai $\mathrm{F}_{\text {hitung }} 9,355 \geq \mathrm{F}_{\text {tabel }} 3,028$ dan nilai sug. $0,000<0,050$ dimana artinya $\mathrm{H}_{0}$ ditolak $\mathrm{H}_{\mathrm{a}}$ diterima. Jadi kesimpulannya terdapat pengaruh signifikan dan positif antara media pembelajaran e-learning dan motivasi belajar pada IPK mahasiswa program studi (prodi) pendidikan ekonomi Universitas Panca Sakti Bekasi.

\section{CONCLUSION}

Berdasarkan hasil penelitian yang dilakukan pada STKIP Panca Sakti Bekasi mengenai "Pengaruh Media Pembelajaran Elektronik (E-Learning) Dan Motivasi Belajar Terhadap Ipk Akademik Mahasiswa Pendidikan Ekonomi Ta 2019/2020 Stkip Panca Sakti", maka penelitian ini dapat disimpulkan :

a). Media Pembelejaran E-Learning Pada IPK Akademik Mahasiswa

Pada penelitian ini adalah untuk mengetahui signifikansi pengaruh media pembelajaran elektronik (elearning) (X1) terhadap IPK Akademik Mahasiswa Semester Ganjil 2019-2020 (Y). Dari hasil analisis dapat dilihat bahwa nilai t hitung untuk variabel media pembelajaran elektronik (elearning) (X1) adalah $3.754>\mathrm{t}$ tabel 1.960 (sig. $0.000<0.05$ ) maka Ho ditolak. Dengan demikian dapat dikatakan bahwa media pembelajaran elektronik (elearning) mempunyai pengaruh yang signifikan terhadap IPK Akademik Mahasiswa Semster Genap 2019-2020 Program Studi Pendidikan Ekonomi di STKIP Panca Sakti.

b). Motivasi Belajar Pada IPK Akademik Mahasiswa

Dalam penelitian ini adalah untuk mengetahui signifikansi pengaruh motivasi belajar (X2) terhadap IPK Akademik Mahasiswa Semester Ganjil 2019-2020 (Y). Dari hasil analisis dapat dilihat bahwa nilai t hitung untuk variabel motivasi belajar (X2) adalah $2.719>$ t tabel 1.960 (sig. $0.007<0.05$ ) maka Ho ditolak. Dengan demikian dapat dikatakan bahwa motivasi belajar (X2) mempunyai pengaruh yang signifikan 
terhadap IPK Akademik Mahasiswa Semster Genap 2019-2020 Program Studi Pendidikan Ekonomi di STKIP Panca Sakti.

\section{REFERENCES}

Aghni, R. I. (2018). Fungsi dan Jenis Media Pembelajaran Dalam Pembelajaran Akuntansi. Jurnal Pendidikan Akuntansi Indonesia, 16(1), 98-107.

Alang, H. M Sattu. (2015). Urgensi Diagnosis dalam Mengatasi Kesulitan Belajar. Al Irsyad- Al Nafs, Jurnal Bimbingan Penyuluhan Islam. Vol 2. No 1. Desember 2015. Hal 1-14.

Aurora, A., \& Effendi, H. (2019). Pengaruh Penggunaan Media Pembelajaran E-learning terhadap Motivasi Belajar Mahasiswa di Universitas Negeri Padang. JTEV (Jurnal Teknik Elektro dan Vokasional), 5(2), 11-16.

Badri, Syofyan. (2012). Metode Statistika untuk Penelitian Kuantitatif. Yogyakarta : Penerbit Ombak.

Fakhrul, Jamal. (2014). Analisis Kesulitan Belajar Siswa dalam Mata Pelajaran Matematika pada Materi Peluang Kelas XI IPA SMA Muhammadiyah Meulaboh Johan Pahlawan. Jurnal MAJU (Pendidikan Matematika). Vol 1. No 1. Maret-September 2014. Hal 18-36.

Hakim, Thursan. (2010). Belajar Secara Efektif. Jakarta : Puspa Suara.

Hamdu, G., \& Agustina, L. (2011). Pengaruh motivasi belajar siswa terhadap prestasi belajar IPA di sekolah dasar. Jurnal penelitian pendidikan, 12(1), 90-96.

Hasyim, M. (2014). Penerapan Fungsi Guru dalam Proses Pembelajaran. Auladuna. Vol 1. No 2. Desember 2014. 265-276

Idris. (2010). Aplikasi Model Analisis Data Kuantitatif Dengan Program SPSS (Edisi Revisi III). Padang : Fakultas Ekonomi UNP.

Jethro, O. O., Grace, A. M., \& Thomas, A. K. (2012). E-learning and its effects on teaching and learning in a global age. International Journal of Academic Research in Business and Social Sciences, 2(1), 203.

Manurung, T. M. S. (2017). Pengaruh motivasi dan perilaku belajar terhadap prestasi akademik mahasiswa. JAS-PT (Jurnal Analisis Sistem Pendidikan Tinggi Indonesia), 1(1), 17-26.

Muhson, A. (2010). Pengembangan media pembelajaran berbasis teknologi informasi. Jurnal Pendidikan Akuntansi Indonesia, 8(2).

Munir. (2008). Kurikulum Berbasis Teknologi Informasi dan Komunikasi. Bandung: Alfabeta.

Nashar. (2004). Peranan Motivasi dan Kemampuan Awal dalam Kegiatan Pembelajaran. Jakarta: Delia Press.

Ningrum, R. F. (2017). IMPLEMENTASI MEDIA PEMBELAJARAN BERBASIS ELEARNING DAN PENGARUHNYA TERHADAP PENINGKATAN MOTIVASI BELAJAR DAN HASIL BELAJAR MAHASISWA. JURNAL LENTERA ICT, 2(1), 67-77.

Nurmala, D. A., Tripalupi, L. E., \& Suharsono, N. (2014). Pengaruh motivasi belajar dan aktivitas belajar terhadap hasil belajar akuntansi. Jurnal Pendidikan Ekonomi Undiksha, 4(1).

Ricardo, R., \& Meilani, R. I. (2017). Impak minat dan motivasi belajar terhadap hasil belajar siswa. Jurnal Pendidikan Manajemen Perkantoran (JPManper), 2(2), 188201. 
Sardiman, A. M. (2012). Interaksi dan Motivasi Belajar Mengajar. Jakarta: Raja Grafindo Persada.

Suharyanto, S., \& Mailangkay, A. B. (2018). Penerapan E-learning sebagai Alat Bantu Mengajar dalam Dunia Pendidikan. Jurnal Ilmiah Widya, 4(3).

Tampil, Y., Komaliq, H., \& Langi, Y. (2017). Analisis Regresi Logistik Untuk Menentukan Faktor-Faktor Yang Mempengaruhi Indeks Prestasi Kumulatif (IPK) Mahasiswa FMIPA Universitas Sam Ratulangi Manado. d'CARTESIAN, 6(2), 5662.

Uno, Hamzah B. (2016). Teori Motivasi \& Pengukurannya: Analisis di Bidang Pendidikan. Jakarta:Bumi Aksara.

Wardiana, W. (2002). Perkembangan teknologi informasi di Indonesia.

Wicaksono, A. (2012). Hubungan Antara Indeks Prestasi Kumulatif dan Nilai Uji Kompetensi Dokter Indonesia pada Dokter Lulusan Universitas Tanjungpura. Jurnal Visi Ilmu Pendidikan, 7(1). 